\title{
EGV: A Methodology Proposal to Educational Games Virtualization
}

\author{
Wilk Oliveira dos Santos ${ }^{1}$ \\ ${ }^{1}$ Laboratory of Applied Computing in Education and Advanced Social Technology (CAEd) - \\ Institute of Mathematical and Computer Sciences - University of São Paulo (USP) - São \\ Carlos, SP - Brazil
}

\begin{abstract}
Games Virtualization is a process of digital versions creation for traditional/ physical games. In education, this process aims to create digital versions for traditional/ physical educational games, keeping the psychological and pedagogical concepts from the traditional version, as well, to associate these concepts to the contemporary game design elements. One of the main challenges in this field is the lack of a specific methodology. In this sense, this study proposes a methodology to Educational Game Virtualization, starting in the traditional game chosen and ending in the evaluation, release, and maintenance of game. An experiment was conducted in order to evaluate the methodology, the results show that the methodology was effective in the games' development, helping the professionals to develop the games, keeping the pedagogical and psychological concepts of traditional games version, associating these concepts to contemporary game design elements.
\end{abstract}

Key-words. educational games, educational game virtualization, methodology

\section{Introduction}

In the last decades, the international industry of game development has been increasing, becoming an important worldwide industry. According to a recent report of Entertainment Software Association (ESA 2015), only in the United States, there are approximately 155 million of players, moving in 2014, approximately $\$ 22.41$ billion around the world. Additionally, another interesting recent study showed that $74 \%$ of $K-8^{l}$ teachers use digital games in the classroom (Lofgren 2015), enabling a considerable growth of the Educational Games industry in the last years.

In the academic context, a series of recent studies have been done in order to investigate effects of video games in different educational aspects (e.g. Anderson et al. (2010), Scoresby and Shelton (2011) and others). These studies have highlighted a series of discussions related to video games positive effects on student's learning, such as game fullness, motivation, and others; and negative effects, such as: violence, social interaction absence and extreme appreciation of "digital" (digital activities conducted using some kind of technological device), in detriment to "traditional" (traditional (physical/ manual) activities).

In order to reduce the effects of extreme appreciation of "digital", recent studies have been addressed Games Virtualization, (e.g. Santos et al. (2015), Oliveira and Silva Junior (2015), dos Santos et al. (2017) and others), in order to create digital versions to traditional/physical Educational Games, aim to keep the pedagogical and psychological aspects from traditional/physical game, and associate these aspects with contemporary game design elements. Like this, recent studies have shown a series of benefits of virtualized games,

\footnotetext{
${ }^{1}$ K-8 schools are schools in the United States that enroll students from kindergarten/pre-K (age 5) through 8th grade (up to age 14), combining the typical elementary school (K-5) and junior high or middle school (6-7-8).
}

V. $16 \mathrm{~N}^{\mathrm{o}} 1$, julho, 2018 
as well as highlighted a series of discussions related to design, application and evaluation of Educational Games developed based on Games Virtualization.

However, because the growing number of studies in Educational Games Virtualization, with highlight to Educational Games development based on this process and the lack of a specifical methodology to Educational Games Virtualization, Santos and Silva Junior (2016) highlighted as a big challenge in this field, the design of a methodology for Educational Games Virtualization.

This study presents a proposal of methodology to Educational Games Virtualization, covering all development process, starting in the traditional game chosen and ending in the evaluation, release, and maintenance of game. In order to evaluate the methodology efficacy, an experiment was conducted with a professional that developed three different educational games using this methodology. The results indicate that the methodology was effective to help the professional to develop the games, following the principles of educational games virtualization.

\section{Background}

This section aims to present the main concepts addressed in this study: Educational Games, Educational Games Virtualization, and some related works.

\subsection{Educational Game}

Over the last 20 years, computer games have been increasingly replaced the more traditional games as leisure activities, and have had a transformational impact on how we spend our leisure time (Connolly et al. 2012). According to these authors, educational games provide engaging activities and it seems like that, far from waning, interest in games for leisure is still growing.

At this point, in the last decades, educational games have been used in many teaching contexts of different topics as: Business, Geography, History, and others (Connolly et al. 2012), as well as studied in different perspectives as violence (Anderson and Gentile 2014), learning (Linehan et al. 2014), playfulness (Scoresby and Shelton 2011), flow experience (dos Santos et al. 2018), and others.

According to recent studies, a series of empirical results related to games-based learning has shown that despite the overwhelming publicity given to the negative impact of games, like most technologies before them, computer games can have both positive and negative impacts (Connolly et al. 2012). These results are important to demonstrate not only the efficacy of games in an educational context but also to highlight the importance of new studies in different kind of educational games, for instance, identify if is capable of providing flow experience for the players.

\subsection{Educational Game Virtualization}

In the contemporary world, the idea of 'virtualization' is considered and studied by philosophy, psychology, physics, biotechnology, arts, and others (Kerimbayev 2015), increasing topics related to virtualization in different contexts as social life, industry, and education. In this perspective, Educational Games Virtualization is a process to create digital versions for traditional/physical Educational Games before used to the teaching of a determined topic. The main goals of Educational Games Virtualization are kept/preserve the aspects of the traditional/physical version of the version of the educational game and combine 
these aspects with the contemporary game design elements, in order to increase students' learning.

Educational Games Virtualization can be used in different contexts and be support in different educational topics. According to Oliveira and Silva Junior (2015), the Educational Games Virtualization process should be start with the choice of the traditional educational game and end with the process of game evaluation, in order to identify if the educational game (in the digital version) keeps/ preserves the main aspects of traditional/physical game version, as well identify if the game can be increase students' learning.

According to Santos et al. (2013) and Santos et al. (2015) this process involves a multidisciplinary team, with professionals from Computer Science (especially HumanComputer Interaction (HCI)), Pedagogy, Psychology and those from specific educational games application fields, for instance Mathematics, Language, Biology, and others, in order to auxiliary the Educational Game Virtualization process.

\subsection{Related Works}

Over the years, different methodologies to Educational Games development has been proposed, Carro et al. (2002) are one of the first to propose a methodology to Educational Games development, they describe an adaptive Educational Game environment and a model that supports the environment design process. The methodology proposed allowed the specification of educational methods that can be used for the game environment generation. This study provided a starting point for new methodologies in this field.

Recently, others studies have been done aiming to provide methodologies to Educational Games development in specifical fields, Nadolski et al. (2008) proposed a methodology named EMERGO to developing and delivering scenario-based serious games that are aimed at the acquisition of complex cognitive skills in higher education. Rocha and Araújo (2015) proposed an interactive methodology and integrative models to develop serious games, integrating a holistic and multidisciplinary approach into the areas of simulation, game, learning, training, and domain.

Aslan and Balci (2015) proposed a methodology named GAMED that consists of a body of methods, rules, and postulates and is embedded within a digital educational game life cycle. The life cycle describes a framework for the organization of the phases, processes, work products, quality assurance activities, and project management activities required to develop, use, maintain, and evolve a digital educational game from birth to retirement.

The methodologies before presented, despite of represent important contributions to academy and industry, generally are focused in specifically points, making it difficult their application in different contexts and scenarios, as well as do not present concerns related to important points of Educational Games Virtualization, for instance, associate the pedagogical and psychological aspects of traditional games to contemporary game design elements, highlighting the importance of to create specifics methodologies to this field.

\section{Proposal}

The proposal of study consists in a 'high level ${ }^{2}$ ' methodology, developed in order to provide a general structure encompassing the main phases of Educational Games Virtualization, starting

\footnotetext{
${ }^{2}$ Concept used to describe operations that are more abstract in nature, where overall goals and systemic features are typically more concerned with the wider, macro system as a whole.
} 
in the choice of traditional game, addressing all game development process and finalizing in the game release and divulgation, aiming to auxiliary professionals regarding Educational Game Design to develop Educational Games based in the Educational Games Virtualization process.

The methodology is composed of three main phases $^{3}$ : Preproduction, Production, and Postproduction. Preproduction phase aims to cover the steps related to the choice of traditional game, requirement analysis and game prototype, Production step, aims to cover steps related to game implementation, from game documentation until the game test, and Postproduction phase, aims to cover steps regarding the game evaluation, release and real use of the game.

Preproduction phase is composed of two general steps: Traditional Game Choice responsible for Problem Evaluation, Requirements Analysis, Functional Requirements and Nonfunctional Requirements, and Prototyping responsible for Physical Prototyping and Virtual Prototyping.

Production phase is composed of four general steps: Game Design responsible to Game Design Document, Project responsible to Game Modeling, Phase Diagrams and Data Base Project, Implementation responsible to Programming, Art, Interface, Scenario, Characters, Resources and Audio, and Test responsible to Component Integration, Test Run, and Test Flow.

Postproduction phase is composed of three general steps: Conceptual Evaluation responsible for Qualitative Evaluation, (Pedagogical Evaluation and Psychological Evaluation), Design Evaluation responsible to Quantitative Evaluation (HCI Evaluation and Game Design Evaluation) and Implantation responsible to Release, Divulgation and game Installation/Activation. Table 1 describes first phase steps, Table 2 describes second phase steps, Table 3 describes third phase steps and Figure 1 presents the general methodology structure.

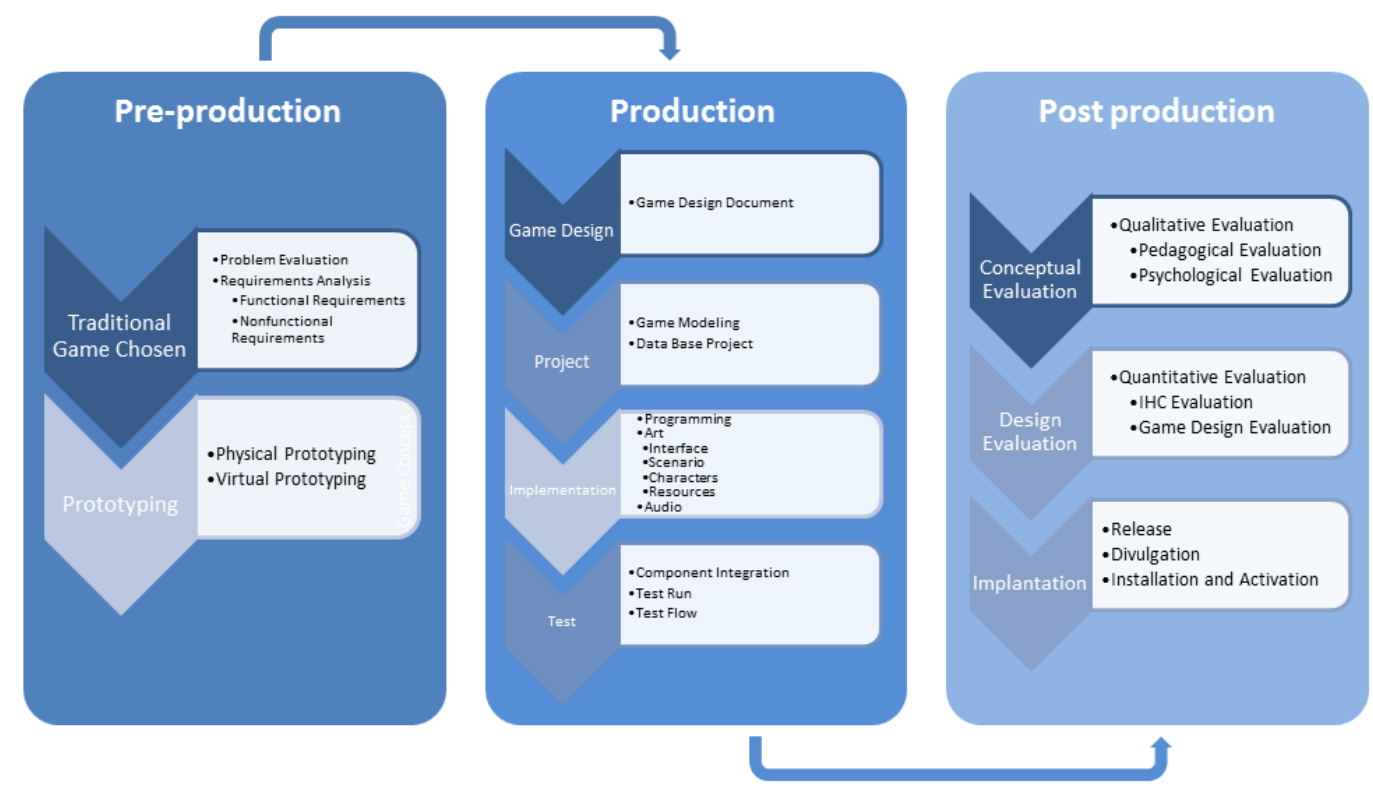

Figure 1: Methodology Structure

\footnotetext{
${ }^{3}$ Only a summary of methodology concept, as well as of the methodology proposed are presented in this paper, however the full description of methodology, and, the main resources associated are available in this link: http://migre.me/tYfpe
} 
Table 1: Pre-production Phase

\begin{tabular}{|c|c|c|c|}
\hline \multirow{4}{*}{ 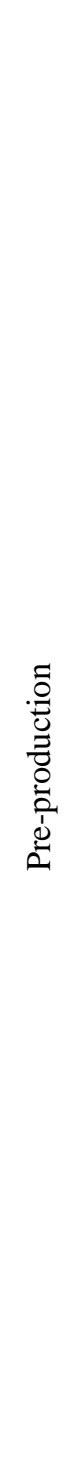 } & \multirow{2}{*}{ 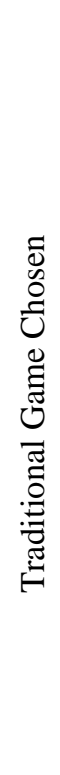 } & $\begin{array}{l}\text { Problem } \\
\text { Evaluation }\end{array}$ & $\begin{array}{l}\text { Consists in the conceptual analysis of the traditional/physical game and their } \\
\text { application in a real scenario. This step aims to identify if is relevant to } \\
\text { submitted the game to Virtualization Process. Only if the game is considerate } \\
\text { relevant to the field of study, should be conducted for next step. This step } \\
\text { should be conducted in partnership with professionals of Pedagogy, } \\
\text { Psychology, and domain of game application (for instance: Math, Language, } \\
\text { Biology, and others), in order to analyses Pedagogical and Psychological } \\
\text { concepts regarding the traditional game. }\end{array}$ \\
\hline & & $\begin{array}{c}\text { Requirements } \\
\text { Analysis }\end{array}$ & $\begin{array}{l}\text { Consists in the educational game requirements identification, this step is } \\
\text { divided into two phases: Functional Requirements (specify a behavior or } \\
\text { function of software (educational game) and Nonfunctional Requirements } \\
\text { (how the educational game should behave and that it is a constraint upon the } \\
\text { behavior of the system). This step aims to identify which Pedagogical and } \\
\text { Psychological concept of the traditional game should remain in the digital } \\
\text { game. After concluded Requirements Analysis, the game can be conducted to } \\
\text { next step. This step should be executed in partnership with professionals of } \\
\text { Pedagogy, Psychology, the domain of game application and Software } \\
\text { Engineering, in order to identify and organize the application requirements. }\end{array}$ \\
\hline & \multirow[b]{2}{*}{$\begin{array}{l}00 \\
0 \\
0 \\
0 \\
0 \\
0 \\
0 \\
0 \\
0\end{array}$} & $\begin{array}{l}\text { Physical } \\
\text { Prototyping }\end{array}$ & $\begin{array}{l}\text { Consists in the Physical Prototype development of the game, this prototype can } \\
\text { be able to use in real context in order to identify main Pedagogical and } \\
\text { Psychological traditional game concepts, as well identify the main traditional } \\
\text { game application nuances. This step should be conducted in partnership with } \\
\text { professionals from Pedagogy, Psychology, the domain of game application and } \\
\text { Game Design in order to identify as Pedagogical and Psychological concepts } \\
\text { can be structured in the digital game. }\end{array}$ \\
\hline & & $\begin{array}{c}\text { Virtual } \\
\text { Prototyping }\end{array}$ & $\begin{array}{l}\text { Consists in the Virtual Prototype development of the game in order to define a } \\
\text { general game structure, as well as identified as the digital game can keep } \\
\text { Pedagogical and Psychological concepts of the traditional game. Similar to } \\
\text { preview step, this step should be conducted in partnership with professionals } \\
\text { of Pedagogy, Psychology, the domain of game application and Game Design } \\
\text { in order to identify as Pedagogical and Psychological concepts can be } \\
\text { structured in the digital game. This step can be conducted simultaneously with } \\
\text { the preview step. After these steps to be completed, Production step can be } \\
\text { started. }\end{array}$ \\
\hline
\end{tabular}

Table 2: Production Phase

\begin{tabular}{|c|c|c|c|}
\hline \multirow{2}{*}{$\begin{array}{l}0 \\
.00 \\
0 \\
0 \\
0 \\
0\end{array}$} & $\begin{array}{l}\frac{.00}{00} \\
0 \\
0 \\
0 \\
\tilde{D} \\
0\end{array}$ & $\begin{array}{l}\text { Game Design } \\
\text { Document }^{4}\end{array}$ & $\begin{array}{l}\text { Consists of the Game Design Document (GDD) - highly descriptive } \\
\text { living design document of the design for a video game - development, in } \\
\text { order to serve as a guideline to the game development process. This step } \\
\text { should be conducted in partnership with professionals of Software } \\
\text { Engineering and Game Design in order to structure and document the } \\
\text { 'game concept' established in the preview steps and serve a guideline to } \\
\text { next steps. After GDD will be completed, the game project can be } \\
\text { conducted to next step. }\end{array}$ \\
\hline & $\frac{\overrightarrow{0}}{0}$ & Game Modeling & $\begin{array}{l}\text { Consists in the conceptual game modeling, defined by a consistent set of } \\
\text { rules to game structure (class diagram) by Software Engineering. This } \\
\text { step also should be defining the resources used in the game development } \\
\text { (programing language, engine, software database and others), according } \\
\text { to the game requirements. This step should be conducted in partnership } \\
\text { with professionals from Software Engineering. }\end{array}$ \\
\hline
\end{tabular}

${ }^{4}$ A GDD can be updated during all project, in other words all changes in the project can be documented in the GDD.

V. $16 \mathrm{~N}^{\mathrm{o}} 1$, julho, 2018 


\begin{tabular}{|c|c|l}
\hline \multirow{5}{*}{ Data Base Project } & $\begin{array}{l}\text { Consists of the development of game Data Base Project (DBP) according } \\
\text { to the conceptual game model defined in the previous step. This step } \\
\text { should be conducted in partnership with professionals regarding Software } \\
\text { Data Base. This step can be conducted simultaneously to preview step } \\
\text { (Game Modeling). }\end{array}$ \\
\hline \multirow{5}{*}{ Programming } & $\begin{array}{l}\text { Consists in the game programming - development of a game version } \\
\text { executable through some programing language and/or game engine } \\
\text { (software framework designed for the creation and development of video } \\
\text { games) - This step should be conducted by professionals of Computer }\end{array}$ \\
\hline \multirow{5}{*}{ Science according to concepts defined in the preview steps. }
\end{tabular}

Table 3: Post Production Phase

\begin{tabular}{l|l|l|l}
\hline & & & $\begin{array}{l}\text { Consist in the conduction of a Qualitative Evaluation in the game (digital } \\
\text { version) in order to identify if the Pedagogical and Psychological } \\
\text { concepts of the traditional game are kept in the digital game, as well as } \\
\text { identify game influence in the students learning. This step should be } \\
\text { conducted in partnership with professionals of Pedagogy and Psychology } \\
\text { (preferably the same professionals of first general step (Pre-production)). }\end{array}$ \\
\hline
\end{tabular}




\begin{tabular}{|c|c|c|}
\hline 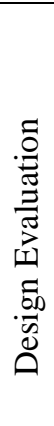 & $\begin{array}{l}\text { Quantitative } \\
\text { Evaluation }\end{array}$ & $\begin{array}{l}\text { Consist in the conduction of a Quantitative Evaluation in the game (digital } \\
\text { version) in order to identify the game design elements influences in the } \\
\text { students' learning, as well as the relationship between Pedagogical and } \\
\text { Psychological concepts of the traditional game and game design elements. } \\
\text { This step should be conducted in partnership with professionals from } \\
\text { Game Design, Graphical Computing (CG) and HCI (preferably the same } \\
\text { professionals of second general step (Production)). These steps } \\
\text { (Conceptual Evaluation and Design Evaluation) can be conducted } \\
\text { simultaneously. After game approval in these steps, the game can be } \\
\text { conducted to next step. }\end{array}$ \\
\hline \multirow{3}{*}{ 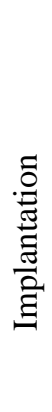 } & Release & $\begin{array}{l}\text { Consist of the game release to different scenarios. This step can be } \\
\text { conducted in according to specific needs of the development team. }\end{array}$ \\
\hline & Divulgation & $\begin{array}{l}\text { Consist of the game divulgation to different scenarios. This step and the } \\
\text { preview step (release) should be conducted in a partnership with } \\
\text { professionals in Marketing. }\end{array}$ \\
\hline & $\begin{array}{l}\text { Installation and } \\
\text { Activation }\end{array}$ & $\begin{array}{l}\text { Consist in provide a runnable game version according to needs and } \\
\text { definitions of the development team. This step should be conducted in a } \\
\text { partnership with professionals in Computer Science in order to identify } \\
\text { and solve possible customer needs. }\end{array}$ \\
\hline
\end{tabular}

\section{Experiment}

The experiment was characterized as a qualitative experiment, based on evaluation in real context Wohlin et al. (2000).

\subsection{Method}

A team composed of seven different professionals (see section 4.2) developed three different Educational Games (Conquering with Rest (Santos et al. 2014) and Challenges with Sticks (Santos et al. 2015)) and Challenges of Diagonals (Santos et al. (2017)) using the methodology $\mathrm{EGV}^{\circledR}$. After the game's development, each educational game developed through the methodology were empirically evaluated in different perspectivities and participants of the development team conducted a qualitative evaluation regarding each methodology step, based on Godoy (1995). Three criteria were established, $(i)$ importance of each step to the complete process, (ii) structure and flow of steps, (iii) cost of implementation (human, financial and computational).

\subsection{Participants}

Participants were a team composed of seven professionals (game designer, IHC specialist, programmer, interface designer, pedagogue, psychologist, and domain specialist (Math Professor)). In the games evaluation step, a total of 39 students participated in the three different experiments (for a complete review about the evaluation of the game with high, see Santos et al. 2015, Oliveira et al. 2015 and Santos et al. 2017).

\section{Results and Discussions}

The results were obtained from the discussions conducted by the professionals, after the use of methodology and through the empirical evaluation of the games virtualized based on the methodology proposal. In this paper, we will keep the focus of discussion in the results based on the professionals' evaluation. The professionals indicate that the prototyping steps were especially important in order to understand which aspect from traditional should be kept in the digital version, as well the methodology steps were important in order to develop the games, 
keeping the pedagogical and psychological aspects from traditional game, allied to the contemporary game design elements. Through the discussion with the professionals, was not identified any problems related to the steps flow. Instead, the steps flow helped the team in order to understand the order of development activities.

During the discussions, the professionals also highlighted that the game evaluation steps (conceptual evaluation and design evaluation), were important in order to understand if the games reached the goals established, especially, if the game maintained the aspects of the traditional game, as well to identify the game consequences in the student's learning. These steps were also important in order to identify that the games developed through this methodology had significant results with students (Oliveira et al. 2015), and reached the main objectives of Educational Games Virtualization.

This study used software free or of low cost (Santos et al. 2014), showing that the methodology should be used in different teams and with different resources, representing an important advantage to teams that do not have financial resources to game development, such as research projects and students groups. We also highlight that according to the game context, the methodology can be adapted, for instance, if the game does not have any kind of audio, the step of audio may be disregarded, on the other hand, because the context of Educational Games Virtualization, others steps such as conceptual evaluation and design evaluation never should be disregarded.

\section{Threats to Validity}

In order to organize this section, the threats to validity were classified using the Internal, External, Construct and Conclusion categories, defined by Wohlin et al. (2000). As an internal threat to validity, the games were developed for a team without the participation of all professionals recommended in the methodology (e.g. music designer and marketing), as well as, some professionals were included in the team during the development process. As external threat to validity, the sample of the experiment is the only representative to the academic context of a Brazil university, thus, there is an interaction of setting and treatment threat. The setting of the experiment must be broadened to obtain more generic results.

As construct threat to validity, we highlight that besides Educational Games Virtualization is a multidisciplinary topic, can be used to develop Educational Games of different fields, such as Language, Biology, Geography, and others, only games to the Math teaching were implemented. Finally, as conclusion threat to validity, the games developed were applied and evaluated with only ten students (the same students to two games), as well as only in a desktop system.

\section{Concluding Remakes}

In the past few years, Educational Game Virtualization have been addressed as a promising topic of Educational Game, especially to provide to students, pedagogical and psychological aspects of traditional/physical games, allied to modern game design approaches $(e . g$. Santos $e t$ al. (2015) and Oliveira and Silva Junior (2015)). However, a big challenge regarding this field is the lack of a methodology to games development.

In order to supply this lack, this paper proposed a methodology to Educational Games Virtualization. The methodology was used to implement/virtualize three different educational games. The methodology was evaluated through a qualitative experiment, with the participation of different professionals and the games virtualized through were empirically evaluated based on some different criteria. Results indicated that the methodology was 
capable of helping the professionals in the game development process, as well as reaching the goals established.

Finally, as general recommendations and future work we highlight the conduction of a large-scale experiment with participation of more professionals using the methodology to development games regarding different fields, such as Biology, Chemistry and Language, and different platforms (e.g. mobile phones and tablets), as well as, conduct an evaluation based on specialist's opinion. We also highlight the development of a specific methodology in order to evaluate the Educational Games developed based on Educational Games Virtualization process.

\section{References}

Anderson, C. A., \& Gentile, D. A. (2014). Violent Video Game effects on Aggressive thoughts, feelings, physiology, and Behavior. Media Violence and Children: A Complete Guide for Parents and Professionals, 229.

Anderson, C. A., Shibuya, A., Ihori, N., Swing, E. L., Bushman, B. J., Sakamoto, A., \& Saleem, M. (2010). Violent video game effects on aggression, empathy, and prosocial behavior in eastern and western countries: a meta-analytic review. Psychological bulletin, 136(2), 151.

Aslan, S., \& Balci, O. (2015). GAMED: digital educational game development methodology. Simulation, 91(4), 307-319.

Babosa, M. B., Rêgo, A. B., \& Medeiros, I. (2015). HEEG: Heuristic Evaluation for Educational Games. In: XIV Brazilian Symposium of Games and Digital Entertainment. Teresina-PI, Brazil.

Carro, R. M., Breda, A. M., Castillo, G., \& Bajuelos, A. L. (2002, May). A methodology for developing adaptive educational-game environments. In Adaptive Hypermedia and Adaptive Web-Based Systems (pp. 90-99). Springer Berlin Heidelberg.

Connolly, T. M., Boyle, E. A., MacArthur, E., Hainey, T., \& Boyle, J. M. (2012). A systematic literature review of empirical evidence on computer games and serious games. Computers \& Education, 59(2), 661-686.

dos Santos, W. O., Bittencourt, I. I., Isotani, S., Dermeval, D., Marques, L. B., \& Silveira, I. F. (2018). Flow Theory to Promote Learning in Educational Systems: Is it Really Relevant?. Brazilian Journal of Computers in Education, 26(02), 29.

dos Santos, W. O., Gomes, T., \& Silva, C. (2017, October). Towards to Flow State Identification in Educational Games: An Empirical Study. In Brazilian Symposium on Computers in Education (Vol. 28, No. 1, p. 927).

Essential facts about the computer and video game industry: 2015 sales, demographic and usage data. Entertainment Software Association, 2015.

Godoy, A. S. (1995). Introdução à pesquisa qualitativa e suas possibilidades. Revista de administração de empresas, 35(2), 57-63.

Kerimbayev, N. (2015). Virtual learning: Possibilities and realization. Education and Information Technologies, 1-13.

Linehan, C., Bellord, G., Kirman, B., Morford, Z. H., \& Roche, B. (2014). Learning curves: analysing pace and challenge in four successful puzzle games. In Proceedings of the first 
ACM SIGCHI annual symposium on Computer-human interaction in play (pp. 181-190). ACM.

Lofgren, K. (2015) 2015 Video Game Statistics \& Trends Who's Playing What \& Why?. Available in: http://www.bigfishgames.com/blog/2015-global-video-game-statswhosplaying-what-and-why/. Accessed: 09/March/2016.

Nadolski, R. J., Hummel, H. G., Van Den Brink, H. J., Hoefakker, R. E., Slootmaker, A., Kurvers, H. J., \& Storm, J. (2008). EMERGO: A methodology and toolkit for developing serious games in higher education. Simulation \& Gaming.

Oliveira, W., \& da Silva Junior, C. G. (2015). Pesquisa, Desenvolvimento e Avaliação de um Jogo para o Ensino de Matemática, Baseado no Processo de Virtualização de Jogos. In Anais dos Workshops do Congresso Brasileiro de Informática na Educação (Vol. 4, No. 1, p. 145).

Oliveira, W., Neto, S., da Silva Junior, C. G., \& Bittencourt, I. I. (2015). Avaliação de Jogos Educativos: Uma Abordagem no Ensino de Matemática. In: Anais do Simpósio Brasileiro de Informática na Educação (Vol. 26, No. 1, p. 657).

Rocha, R., \& Araújo, R. B. (2015). Metodologia iterativa e modelos integradores para desenvolvimento de jogos sérios de treinamento e avaliação de desempenho humano. In: Anais dos Workshops do Congresso Brasileiro de Informática na Educação (Vol. 4, No. 1, p. 13).

Santos, W. O., \& Silva Junior, C. G. (2016). State of the Art in Educational Games Virtualization. RENOTE, 14(1).

Santos, W. O.; Silva Junior, C. G. (2016). Challenges of Games Virtualization Applied to Educational Games. In: V Workshop of Challenges of Computers in Education. Porto Alegre - RS, Brazil.

Santos, W. O.; Silva, A. P.; \& Silva Junior, C. G. (2014). Conquistando com o Resto: Virtualização de um Jogo para o Ensino de Matemática. In Anais do Simpósio Brasileiro de Informática na Educação (Vol. 25, No. 1, p. 317).

Santos, W., O.; Souza, A., A.; da Silva, A., K., T.; Oliveira, M., L., S.; Silva Neto, S., R.; Rodrigues, A. N., Silva Junior, C. G. (2015) Development Process of an Educational Game: An experience in Brazil. In: XIV Brazilian Symposium of Games and Digital Entertainment. Teresina-PI, Brazil.

Santos, W., Silva Neto, S. R., \& Silva Junior, C. G. (2013). Uso de Games no ensino da Matemática. Uma proposta de virtualização dos jogos tradicionais, para uso como mecanismo de apoio ao processo de ensino e aprendizagem. In: Anais do Simpósio Hipertexto e Tecnologias na Educação, Recife-PE.

Scoresby, J., \& Shelton, B. E. (2011). Visual perspectives within educational computer games: effects on presence and flow within virtual immersive learning environments. Instructional Science, 39(3), 227-254.

Silva Neto, S. R., Santos, H. R., Souza A. A., Santos W. O. (2013) Jogos Educacionais como Ferramenta de Auxílio em Sala de Aula. In: Anais do Workshop de Informática na Escola (Vol. 1, No. 1, p. 130).

Wohlin C, Runeson P, Höst M, Ohlsson MC, Regnell B, Wesslén A (2000) Experimentation in software engineering: an introduction. Kluwer Academic Publishers, Norwell. 